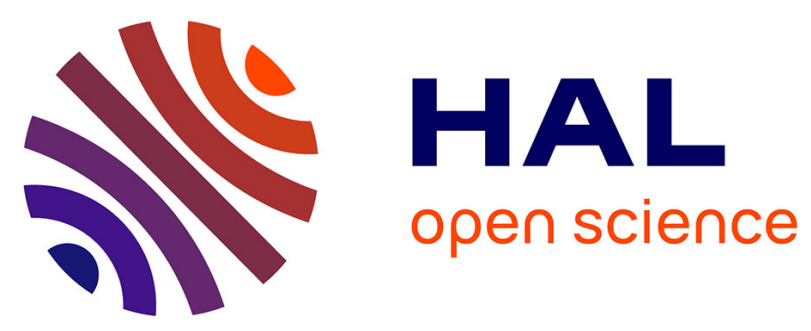

\title{
Hardness and friction behavior of bulk CoAl2O4 and Co-Al2O3 composite layers formed during Spark Plasma Sintering of CoAl2O4 powders
}

Anthony Pavia, Christophe Laurent, Alicia Weibel, Alain Peigney, Geoffroy Chevallier, Claude Estournès

\section{To cite this version:}

Anthony Pavia, Christophe Laurent, Alicia Weibel, Alain Peigney, Geoffroy Chevallier, et al.. Hardness and friction behavior of bulk $\mathrm{CoAl} 2 \mathrm{O} 4$ and $\mathrm{Co}-\mathrm{Al} 2 \mathrm{O} 3$ composite layers formed during Spark Plasma Sintering of CoAl2O4 powders. Ceramics International, 2012, vol. 38, pp. 5209-5217. 10.1016/j.ceramint.2012.03.028 . hal-00836793

\section{HAL Id: hal-00836793 https://hal.science/hal-00836793}

Submitted on 21 Jun 2013

HAL is a multi-disciplinary open access archive for the deposit and dissemination of scientific research documents, whether they are published or not. The documents may come from teaching and research institutions in France or abroad, or from public or private research centers.
L'archive ouverte pluridisciplinaire HAL, est destinée au dépôt et à la diffusion de documents scientifiques de niveau recherche, publiés ou non, émanant des établissements d'enseignement et de recherche français ou étrangers, des laboratoires publics ou privés. 


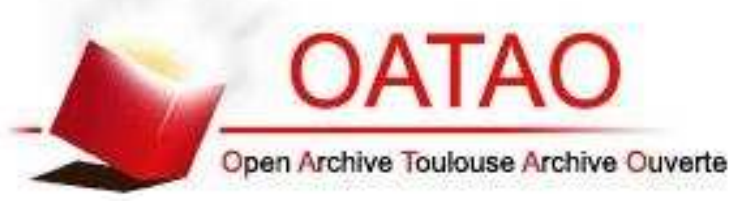

\section{Open Archive Toulouse Archive Ouverte (OATAO)}

OATAO is an open access repository that collects the work of Toulouse researchers and makes it freely available over the web where possible.

This is an author-deposited version published in: http://oatao.univ-toulouse.fr/ Eprints ID: 8725

To link to this article: DOI:10.1016/j.ceramint.2012.03.028 Official URL: http://dx.doi.org/10.1016/j.ceramint.2012.03.028

\section{To cite this version:}

Pavia, Anthony and Laurent, Christophe and Weibel, Alicia and Peigney, Alain and Chevallier, Geoffroy and Estournès, Claude Hardness and friction behavior of bulk CoAl2O4 and Co-Al2O3 composite layers formed during Spark Plasma Sintering of CoAl2O4 powders. (2012) Ceramics International, vol. 38 ( $\left.\mathrm{n}^{\circ} 6\right)$. pp. 5209-5217. ISSN 0272-8842

Any correspondence concerning this service should be sent to the repository administrator: staff-oatao@inp-toulouse.fr 


\title{
Hardness and friction behavior of bulk $\mathrm{CoAl}_{2} \mathrm{O}_{4}$ and $\mathrm{Co}-\mathrm{Al}_{2} \mathrm{O}_{3}$ composite layers formed during Spark Plasma Sintering of $\mathrm{CoAl}_{2} \mathrm{O}_{4}$ powders
}

\author{
Anthony Pavia, Christophe Laurent *, Alicia Weibel, Alain Peigney, \\ Geoffroy Chevallier, Claude Estournès
}

Université de Toulouse, Institut Carnot CIRIMAT, UPS CNRS, Université Paul-Sabatier, 31062 Toulouse cedex 9, France

\begin{abstract}
Materials made up of a $\mathrm{Co}-\mathrm{Al}_{2} \mathrm{O}_{3}$ composite coating over a $\mathrm{CoAl}_{2} \mathrm{O}_{4}$ core are prepared during Spark Plasma Sintering of CoAl $\mathrm{O}_{4}$ powders. The Co particles are precipitated because of a combination of high temperature and low $\mathrm{O}_{2}$ partial pressure. The precipitation and densification processes hamper each other and thus the way the uniaxial pressure is applied during the sintering cycle is an important parameter to control the microstructure of composite layer and its thickness (about $100 \mu \mathrm{m}$ ) and obtain a dense sample $\left(\right.$ about $4 \mathrm{~g} / \mathrm{cm}^{3}$ ). The friction coefficient of the Co$\mathrm{Al}_{2} \mathrm{O}_{3}$ composites against an $\mathrm{Al}_{2} \mathrm{O}_{3}$ ball is lower than that found for an $\mathrm{Al}_{2} \mathrm{O}_{3}$ specimen, which could reveal the lubricating role of submicrometer Co particles. However, increasing the load from 5 to $10 \mathrm{~N}$ load causes major changes in the friction contact, which are detrimental. $\mathrm{Bulk} \mathrm{CoAl}_{2} \mathrm{O}_{4}$ was found to have a Vickers microhardness about $15.5 \mathrm{GPa}$ and an average friction coefficient lower than that of an $\mathrm{Al}_{2} \mathrm{O}_{3} \mathrm{sample}$
\end{abstract}

Keywords: B. Composites; C. Friction; D. Spinels; Spark Plasma Sintering

\section{Introduction}

Metal- $\mathrm{Al}_{2} \mathrm{O}_{3}$ ceramic matrix nanocomposites and nano/ micro hybrid composites could be interesting for tribological applications [1-6], although some authors [7] suggested that metal particles may be detrimental and that oxide $-\mathrm{Al}_{2} \mathrm{O}_{3}$ composites may be more desirable. The preparation of metal$\mathrm{Al}_{2} \mathrm{O}_{3}$ composites usually involves firstly the synthesis of a metal- $\mathrm{Al}_{2} \mathrm{O}_{3}$ composite powder and then its consolidation by hot-pressing or Spark Plasma Sintering (SPS). However, it was shown that materials with a $\mathrm{Fe}-\mathrm{Al}_{2} \mathrm{O}_{3}$ or $\mathrm{Fe} / \mathrm{Cr}-\mathrm{Al}_{2} \mathrm{O}_{3}$ composite layer at the surface could be directly prepared by SPS of a powder of a reactive oxide solid solution $\left(\alpha-\mathrm{Al}_{1.86} \mathrm{Fe}_{0.14} \mathrm{O}_{3}\right.$ or $\alpha-\mathrm{Al}_{2-2 x}\left(\mathrm{Fe}_{0.8} \mathrm{Cr}_{0.2}\right)_{2 x} \mathrm{O}_{3}$, respectively) $[5,8,9]$. The core of the material is made up of the spinel $\mathrm{FeAl}_{2} \mathrm{O}_{4}$ and $\mathrm{Al}_{2} \mathrm{O}_{3}$ (and the surface may contain $\mathrm{FeAl}_{2} \mathrm{O}_{4}$ too depending on the experimental conditions). Other authors [7]

\footnotetext{
* Corresponding author at: Université de Toulouse, Institut Carnot CIRIMAT, UPS CNRS, Université Paul-Sabatier, 118 route de Narbonne, 31062 Toulouse cedex 9, France. Tel.: +33 5615561 22; fax: +33561556163.

E-mail address: laurent@chimie.ups-tlse.fr (Ch. Laurent).
}

also reported the formation of $\mathrm{Fe}-\mathrm{FeAl}_{2} \mathrm{O}_{4}-\mathrm{Al}_{2} \mathrm{O}_{3}$ nanocomposites by aging sintered solid solutions in $\mathrm{N}_{2}-\mathrm{H}_{2}$ gas atmosphere. The first aim of this paper is to study the in situ formation of $\mathrm{Co}-\mathrm{Al}_{2} \mathrm{O}_{3}$ coatings during SPS of $\mathrm{CoAl}_{2} \mathrm{O}_{4}$ powders. $\mathrm{CoAl}_{2} \mathrm{O}_{4}$, a defined-compound as opposed to a solid solution, is a normal spinel, i.e. the $\mathrm{Co}^{2+}$ ions are located in the tetrahedral sites of the cubic close-packing of $\mathrm{O}^{2-}$ ions whereas the $\mathrm{Al}^{3+}$ ions occupy the octahedral sites. Moreover, a considerable solidsolution range exists on the $\mathrm{Al}_{2} \mathrm{O}_{3}$-rich side of the stoichiometric spinels [10,11]. The second aim is to investigate the microhardness and friction behavior of the $\mathrm{Co}-\mathrm{Al}_{2} \mathrm{O}_{3}$ composite layers and of the core of the specimens, made up of bulk $\mathrm{CoAl}_{2} \mathrm{O}_{4}$.

\section{Materials and methods}

\subsection{Powder synthesis}

Three different $\mathrm{CoAl}_{2} \mathrm{O}_{4}$ powders were investigated. The first one, designated COM in the following, is a commercial powder (Aldrich 633631-25G, <50 nm, 99.9\%). The other powders were prepared by combustion synthesis, using the 
appropriate amounts of $\mathrm{Co}\left(\mathrm{NO}_{3}\right)_{2} \cdot 6 \mathrm{H}_{2} \mathrm{O}$ and $\mathrm{Al}\left(\mathrm{NO}_{3}\right)_{3} \cdot 9 \mathrm{H}_{2} \mathrm{O}$ as the oxidizers and either citric acid or urea as the fuel, in a procedure similar to that described elsewhere [12-14]. Note that the combustion with urea is much more violent, reaching a higher temperature than that with citric acid (smouldering combustion). The combustion products were manually ground in an agate mortar and calcined in air $\left(500{ }^{\circ} \mathrm{C}, 2 \mathrm{~h}\right.$ of dwell time) in order to oxidize any possible residual carbon in the asprepared powders, producing powders designated $\mathrm{U}$ and $\mathrm{CA}$ in the following. The powders were divided into several batches as required for the study.

\subsection{Spark plasma sintering}

The powders were consolidated by SPS (Dr Sinter 2080, SPS Syntex Inc., Japan). They were loaded into an $8 \mathrm{~mm}$ inner diameter graphite die. A sheet of graphitic paper was placed between the punch and the powder as well as between the die and the powder for easy removal. This ensemble is known as the stack. The powders were sintered in vacuum (residual cell pressure about $5 \mathrm{~Pa}$ ). A pulse configuration of twelve pulses (one pulse duration $3.3 \mathrm{~ms}$ ) followed by two periods $(6.6 \mathrm{~ms})$ of zero current was used. An optical pyrometer, focused on a little hole at the surface of the die, was used to measure the temperature. A heating rate of $300{ }^{\circ} \mathrm{C} / \mathrm{min}$ was used from room temperature to $700{ }^{\circ} \mathrm{C}$, where a 1 min dwell was applied, and from 700 to $1300{ }^{\circ} \mathrm{C}$. A dwell of 5 min was applied at $1300{ }^{\circ} \mathrm{C}$. Cooling rate was $100^{\circ} \mathrm{C} / \mathrm{min}$. Note that for the first part of the study, the applied uniaxial pressure was kept at a minimum $(5 \mathrm{MPa})$, i.e. the contact pressure, during the full cycle. The sintered specimens are designated COMS1, CAS1 and US1 in the following. The sintered specimens are pellets $8 \mathrm{~mm}$ in diameter and about $2 \mathrm{~mm}$ thick. The sintering experimental conditions are summarized in Table 1.

For the second part of the study, a dwell time of either 3 or 9 min was applied at $1300{ }^{\circ} \mathrm{C}$ and the maximum uniaxial pressure was increased to $100 \mathrm{MPa}$. It was applied by four different ways, increasingly early in the cycle: during the last minute of the dwell (samples US2(3) and US2(9)), during the first minute of the dwell (US3), during the first minute of the $700-1300{ }^{\circ} \mathrm{C}$ ramp (US4), during the first minute of the RT$700{ }^{\circ} \mathrm{C}$ ramp (US5). The sintered specimens are pellets $8 \mathrm{~mm}$ in diameter and about $2 \mathrm{~mm}$ thick. The sintering experimental conditions are summarized in Table 1.

For the last part of the study, three pellets $20 \mathrm{~mm}$ in diameter were prepared by SPS, two using the U powder and one using the COM powder. Specimen US6 was consolidated in conditions similar to that used for US2(9). Specimen US7 and COMS2 were consolidated in conditions similar to that used for US4, except that the dwell time was doubled $(6 \mathrm{~min})$. The sintering experimental conditions are summarized in Table 2.

\subsection{Characterization}

The specific surface area of the powders was measured by the BET method (Micrometrics Flow Sorb II 2300) using $\mathrm{N}_{2}$ adsorption at liquid $\mathrm{N}_{2}$ temperature. Detection and identification of the crystallized phases was performed by X-ray diffraction (XRD, $\mathrm{Cu} \mathrm{K}_{\alpha}$ radiation, Bruker D4 Endeavor). The powders (metalized with $\mathrm{Pt}$ ) were observed by field-emissiongun scanning electron microscopy (FESEM, JEOL JSM 6700F).

The density of the sintered specimens was calculated from the weight and dimensions after removal of the graphitic surface sheet by a light polishing. The pellets $8 \mathrm{~mm}$ in diameter were cut in their middle along the pressing axis using a diamond blade. One half was used for XRD investigations performed on the semi-circular surfaces, first on the unpolished one, then on samples ground ever deeper, in order to reveal the crystallized phases present at various depths into the material. The other half was used as a cross-section, which was polished to a $1 \mu \mathrm{m}$ diamond suspension and was observed by FESEM. For the pellets $20 \mathrm{~mm}$ in diameter, the top side was only slightly polished in order to reveal the surface composite layer. By contrast, the bottom side was ground in order to reveal the core of the specimen. Both surfaces were observed by FESEM. A small portion of the sample was cut and observed as a cross section.

Table 1

Specific surface area of the starting powder $\left(S_{\mathrm{w}}\right)$; SPS experimental conditions: maximum temperature $(T)$, uniaxial pressure $(P)$, dwell time $(t)$, density $(\rho)$; characterization of the specimens: composition of the core, composition and thickness $\left(d_{\mathrm{s}}\right)$ of the surface layer, size range $\left(d_{\mathrm{Co}}\right)$ of the Co particles. sp, spinel, $\alpha, \alpha-$ $\mathrm{Al}_{2} \mathrm{O}_{3} ; \mathrm{nm}$, not measured.

\begin{tabular}{|c|c|c|c|c|c|c|c|c|c|}
\hline Specimen & $\begin{array}{l}S_{\mathrm{w}} \\
\left(\mathrm{m}^{2} / \mathrm{g}\right)\end{array}$ & $\begin{array}{l}T \\
\left({ }^{\circ} \mathrm{C}\right)\end{array}$ & $\begin{array}{l}P \\
(\mathrm{MPa})\end{array}$ & $\begin{array}{l}t \\
t \\
(\min )\end{array}$ & $\begin{array}{l}\rho \\
\left(\mathrm{g} / \mathrm{cm}^{3}\right)\end{array}$ & Core composition & Surface composition & $\begin{array}{l}d_{\mathrm{S}} \\
(\mu \mathrm{m})\end{array}$ & $\begin{array}{l}d_{\mathrm{Co}} \\
(\mu \mathrm{m})\end{array}$ \\
\hline COMS1 & 55 & 1300 & 5 & 0 & 3.2 & $\operatorname{sp}(+\operatorname{Co}+\alpha)$ & $\mathrm{Co}+\alpha$ & Ill-defined & $0.03 / 0.50-1.0$ \\
\hline CAS1 & 78 & 1300 & 5 & 0 & 2.6 & $\mathrm{Co}+\alpha$ & $\mathrm{Co}+\alpha$ & no & $0.45-0.60$ \\
\hline US1 & 18 & 1300 & 5 & 0 & 3.4 & $\mathrm{sp}(+\mathrm{Co})$ & $\mathrm{Co}+\alpha$ & 240 & $0.80-1.0 / 2.0-3.5$ \\
\hline US2(3) & 18 & 1300 & $100^{\mathrm{a}}$ & 3 & 3.8 & $\mathrm{sp}(+\mathrm{Co})$ & $\mathrm{Co}+\alpha$ & 202 & $\mathrm{~nm}$ \\
\hline US2(9) & 18 & 1300 & $100^{\mathrm{a}}$ & 9 & 3.5 & $\mathrm{sp}(+\mathrm{Co})$ & $\mathrm{Co}+\alpha$ & 436 & $\mathrm{~nm}$ \\
\hline US3 & 18 & 1300 & $100^{\mathrm{b}}$ & 3 & 3.9 & $\mathrm{sp}(+\mathrm{Co})$ & $\mathrm{Co}+\alpha$ & 161 & $\mathrm{~nm}$ \\
\hline US4 & 18 & 1300 & $100^{\mathrm{c}}$ & 3 & 4.1 & $\mathrm{sp}(+\mathrm{Co})$ & $\mathrm{Co}+\alpha$ & 98 & $\mathrm{~nm}$ \\
\hline US5 & 18 & 1300 & $100^{\mathrm{d}}$ & 3 & 4.1 & $\mathrm{sp}(+\mathrm{Co})$ & $\mathrm{Co}+\alpha$ & 57 & $\mathrm{~nm}$ \\
\hline
\end{tabular}

\footnotetext{
${ }^{\text {a }}$ Pressure applied during the last minute of the dwell.

b Pressure applied during the first minute of the dwell.

c Pressure applied during the first minute of the $700-1300{ }^{\circ} \mathrm{C}$ ramp.

${ }^{\mathrm{d}}$ Pressure applied during the first minute of the room temperature $-700{ }^{\circ} \mathrm{C}$ ramp.
} 
Table 2

Uniaxial pressure $(P)$, dwell time $(t)$, density $(\rho)$, thickness $\left(d_{\mathrm{s}}\right)$ of the surface composite layer, size $\left(d_{\mathrm{Co}}\right)$ of the Co particles population $(\mathrm{s})$, fraction of surface area occupied by Co particles $\left(S_{\mathrm{Co}}\right)$, Vickers microhardness of the core $\left(\mathrm{HV}_{\text {core }}\right)$ and surface $\left(\mathrm{HV}_{\text {surf }}\right)$, average friction coefficient of the core $\left(\mu_{\text {core }}\right)$ and surface $\left(\mu_{\text {surf }}\right)$ for applied loads of 5 and $10 \mathrm{~N}$, for the specimens prepared by SPS (maximum temperature $1300{ }^{\circ} \mathrm{C}$ ).

\begin{tabular}{|c|c|c|c|c|c|c|c|c|c|c|c|c|}
\hline \multirow[t]{2}{*}{ Specimen } & \multirow{2}{*}{$\begin{array}{l}P \\
(\mathrm{MPa})\end{array}$} & \multirow{2}{*}{$\begin{array}{l}t \\
t \\
(\min )\end{array}$} & \multirow{2}{*}{$\begin{array}{l}\rho \\
\left(\mathrm{g} / \mathrm{cm}^{3}\right)\end{array}$} & \multirow{2}{*}{$\begin{array}{l}d_{\mathrm{S}} \\
(\mu \mathrm{m})\end{array}$} & \multirow{2}{*}{$\begin{array}{l}d_{\mathrm{Co}} \\
(\mu \mathrm{m})\end{array}$} & \multirow{2}{*}{$\begin{array}{l}S_{\mathrm{Co}} \\
(\%)\end{array}$} & \multirow{2}{*}{$\begin{array}{l}\mathrm{HV}_{\text {core }} \\
(\mathrm{GPa})\end{array}$} & \multirow{2}{*}{$\begin{array}{l}\mathrm{HV}_{\text {surf }} \\
(\mathrm{GPa})\end{array}$} & \multicolumn{2}{|l|}{$\mu_{\text {core }}$} & \multicolumn{2}{|l|}{$\mu_{\text {surf }}$} \\
\hline & & & & & & & & & $5 \mathrm{~N}$ & $10 \mathrm{~N}$ & $5 \mathrm{~N}$ & $10 \mathrm{~N}$ \\
\hline US6 & $100^{\mathrm{a}}$ & 9 & 3.5 & 420 & $0.3 / 3.0$ & 23 & 15.5 & 9.6 & 0.28 & 0.31 & 0.27 & 0.51 \\
\hline US7 & $100^{\mathrm{b}}$ & 6 & 3.9 & 145 & $0.3 / 1.5$ & 24 & 14.9 & 8.3 & 0.30 & 0.30 & 0.61 & 0.58 \\
\hline COMS2 & $100^{\mathrm{b}}$ & 6 & 4.1 & 65 & $0.3-1.0$ & 17 & 15.9 & 13.6 & 0.31 & 0.34 & 0.23 & 0.31 \\
\hline
\end{tabular}

a Pressure applied during the last minute of the dwell.

b Pressure applied during the first minute of the $700-1300{ }^{\circ} \mathrm{C}$ ramp.

\subsection{Indentation and friction tests}

Indentation tests $(10 \mathrm{~N}$ for $10 \mathrm{~s}$ in air at room temperature) were performed on both the top and bottom polished surfaces of the $20 \mathrm{~mm}$ pellets (i.e. the surface composite layer and the core) by loading with a Vickers indenter (Shimadzu HMV 2000). The calculated microhardness (HV) values are the average of 10 measurements.

Dry friction experiments were performed using a ball-onreciprocating flat geometry. An alumina ball (TCP-C-AA-0063, CSM, Switzerland) $6 \mathrm{~mm}$ in diameter was used against flat samples surfaces. The normal load was fixed at 5 and $10 \mathrm{~N}$ and the sliding speed was fixed at $5 \mathrm{~cm} / \mathrm{s}$. The reciprocating stroke was $20 \mathrm{~mm}$ and the test was performed for 500 cycles. The frictional force transferred to a load cell was recorded throughout the tests.

\section{Results and discussion}

\subsection{Powders}

Only the peaks typical of $\mathrm{CoAl}_{2} \mathrm{O}_{4}$ are present at the XRD patterns of the three powders (Fig. 1). The crystallite size was evaluated by applying Scherrer's equation on the (2 20 ), (3 111 ) and (4 40$)$ peaks. The obtained values, after subtraction of the instrumental broadening obtained by routine calibration of an alumina sample, are similar and were averaged. The crystallite size is equal to $34 \pm 7 \mathrm{~nm}, 21 \pm 3 \mathrm{~nm}$ and $32 \pm 4 \mathrm{~nm}$ for powders COM, CA and U, respectively. The specific surface area is equal to 55,78 and $18 \mathrm{~m}^{2} / \mathrm{g}$ for powders COM, CA and $\mathrm{U}$, respectively (Table 1). FESEM observations reveal that powder COM (Fig. 2a and b) is made up of loose aggregates about 10$70 \mu \mathrm{m}$ in size, consisting of $25 \mathrm{~nm}$ primary grains. Powder CA (Fig. 2c and d) is made up of slightly porous grains below $40 \mu \mathrm{m}$ in size, consisting of fine primary grains $(<25 \mathrm{~nm})$. By contrast, for powder $U$ (Fig. 2e and f), the grains are dense, formed of sintered primary grains (ca. $50 \mathrm{~nm}$ ) with some large pores. These observations are in reasonable agreement with the XRD and specific surface area data and with earlier works [10-12].

\subsection{Sintered specimens}

The density is equal to $3.2,2.6$ and $3.4 \mathrm{~g} / \mathrm{cm}^{3}$ for COMS1, CAS1 and US1, respectively ( $\rho-$ Table 1$)$. The XRD patterns
(Fig. 3a) of the surface of all three specimens show the Co (1 11 1) peak and other peaks accounting for $\alpha-\mathrm{Al}_{2} \mathrm{O}_{3}$. No spinel peaks are detected. This reveals the formation of a composite layer at the surface. The three specimens were ground to remove this layer and expose the core of the samples. The corresponding XRD patterns are shown in Fig. 3b. For COMS1, the spinel peaks are detected along with the Co (llll) peak (weak) and $\alpha-\mathrm{Al}_{2} \mathrm{O}_{3}$ peaks (very weak). For CAS1, peaks of Co and $\alpha-\mathrm{Al}_{2} \mathrm{O}_{3}$ only are detected, thus similarly to the surface XRD patterns. By contrast, only spinel peaks and a very weak (1 11 1) Co peak are detected for US1 core. The cross-sections of the specimens were observed by FESEM (Fig. 4). The presented results are for the top side of the specimens, close to the upper punch, but it was verified that the same results are obtained close to the bottom punch. In the FESEM images (back-scattered electron images in chemical contrast mode), the Co particles appear as white dots, the spinel phase as light-gray grains and $\alpha-\mathrm{Al}_{2} \mathrm{O}_{3}$ as dark-gray grains (although the latter compounds are difficult to distinguish from each other). The average diameter of the Co particles $\left(d_{\mathrm{Co}}-\right.$ Table 1$)$ was evaluated by measuring the diameter of about one hundred

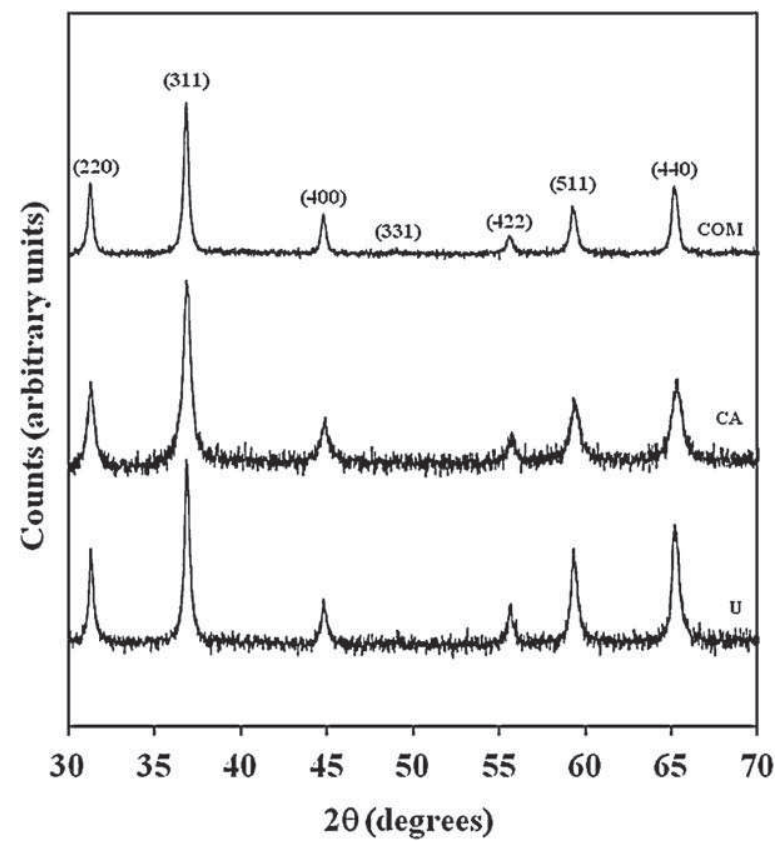

Fig. 1. XRD patterns of the different $\mathrm{CoAl}_{2} \mathrm{O}_{4}$ powders: COM, CA and U. 

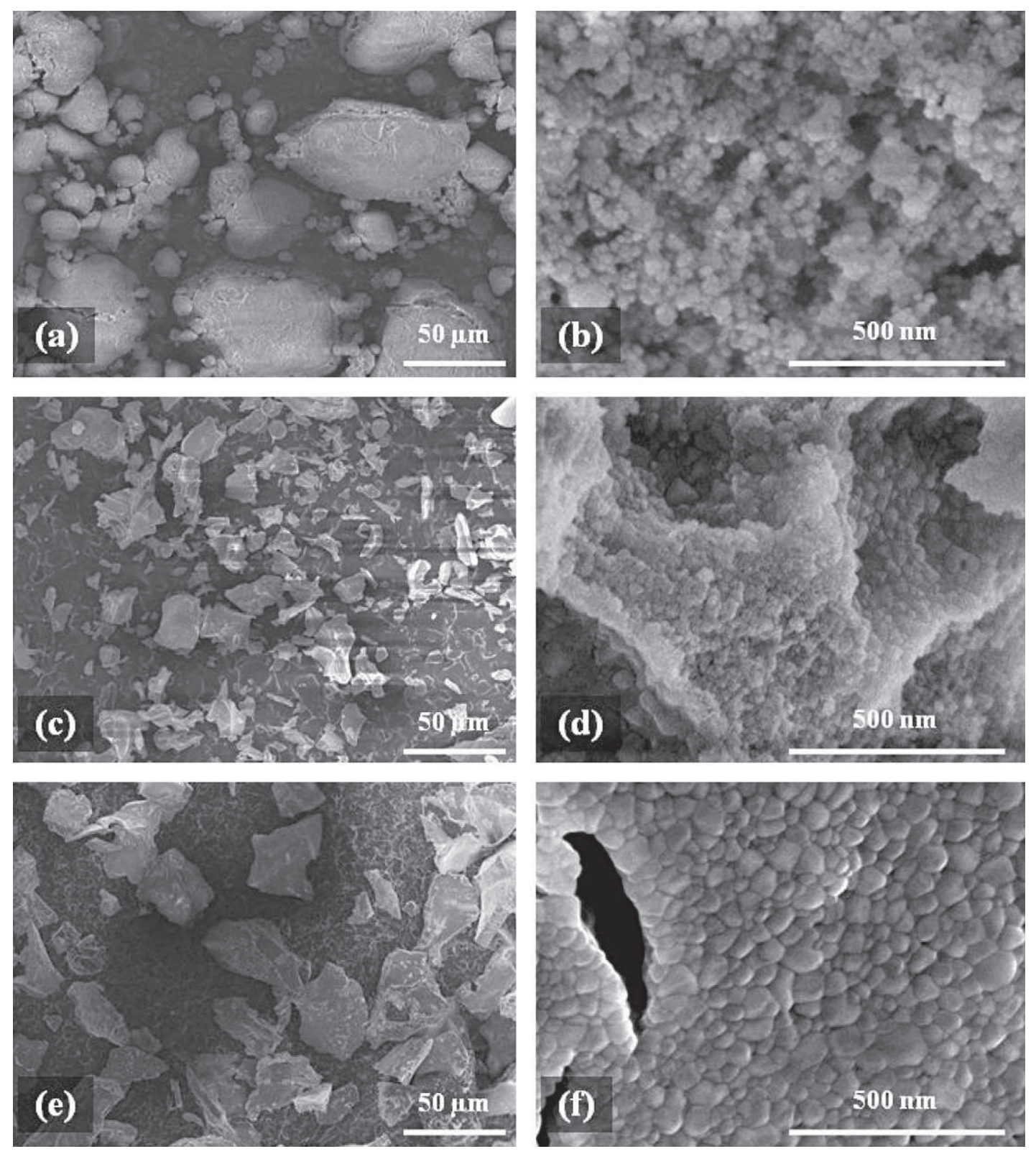

Fig. 2. Low and high magnification FESEM images of the COM (a and b), CA (c and d) and $\mathrm{U}(\mathrm{e}$ and $\mathrm{f}) \mathrm{CoAl}_{2} \mathrm{O}_{4}$ powders.

particles on such images. For COMS1 (Fig. 4a), the transition between the composite layer and the core is ill-defined, possibly because the core also contains $\mathrm{Co}$ and $\alpha-\mathrm{Al}_{2} \mathrm{O}_{3}$. The composite layer (Fig. 4b) is made up of areas containing Co particles of markedly different sizes $(0.03$ and $0.5-1.0 \mu \mathrm{m})$. For CAS1 (Fig. 4c and d), the specimen is very porous and is homogeneous $(0.45-0.60 \mu \mathrm{m}$ Co particles are observed everywhere), in agreement with XRD data. The CA powder is the one with the higher specific surface area, therefore reduction was easier and the $\mathrm{Co}-\mathrm{Al}_{2} \mathrm{O}_{3}$ composite was formed throughout the sample and thus no boundary exists. For US1, the transition between the composite layer $(240 \mu \mathrm{m}$ thick) and the core is sharp (Fig. 4e). The microstructure resembles that of COMS1 with two populations of Co particles but with significantly higher sizes $(0.80-1.0$ and $2.0-3.5 \mu \mathrm{m})$ (Fig. 4f).
Several specimens were sintered using powder $U$ because the transition between the core and the composite layer is sharp. The uniaxial pressure is applied increasingly early for the US2, US3, US4 and US5 specimens, respectively (Section 2.2 and Table 1). For all samples, the XRD patterns (not shown) of the surface and core are similar to that for US1 (Fig. 3), i.e. Co and $\alpha-\mathrm{Al}_{2} \mathrm{O}_{3}$ are detected at the surface whereas $\mathrm{Co}$ (very weak) and $\mathrm{CoAl}_{2} \mathrm{O}_{4}$ are detected at the core (Table 1$)$. The thickness of the composite layer $\left(d_{\mathrm{S}}-\right.$ Table 1$)$, measured on FESEM images (not shown) similar to that shown on Fig. 4e, is shown in Fig. 5 versus the density of the specimens; sample US1 with no applied pressure was also included for comparison. Applying the pressure early in the cycle favors densification $\left(4.09 \mathrm{~g} / \mathrm{cm}^{3}\right.$ for US5) but hampers the transformation of $\mathrm{CoAl}_{2} \mathrm{O}_{4}$ into $\mathrm{Co}$ and $\mathrm{Al}_{2} \mathrm{O}_{3}$, the thickness of the composite layer being the lowest $(57 \mu \mathrm{m})$ for 

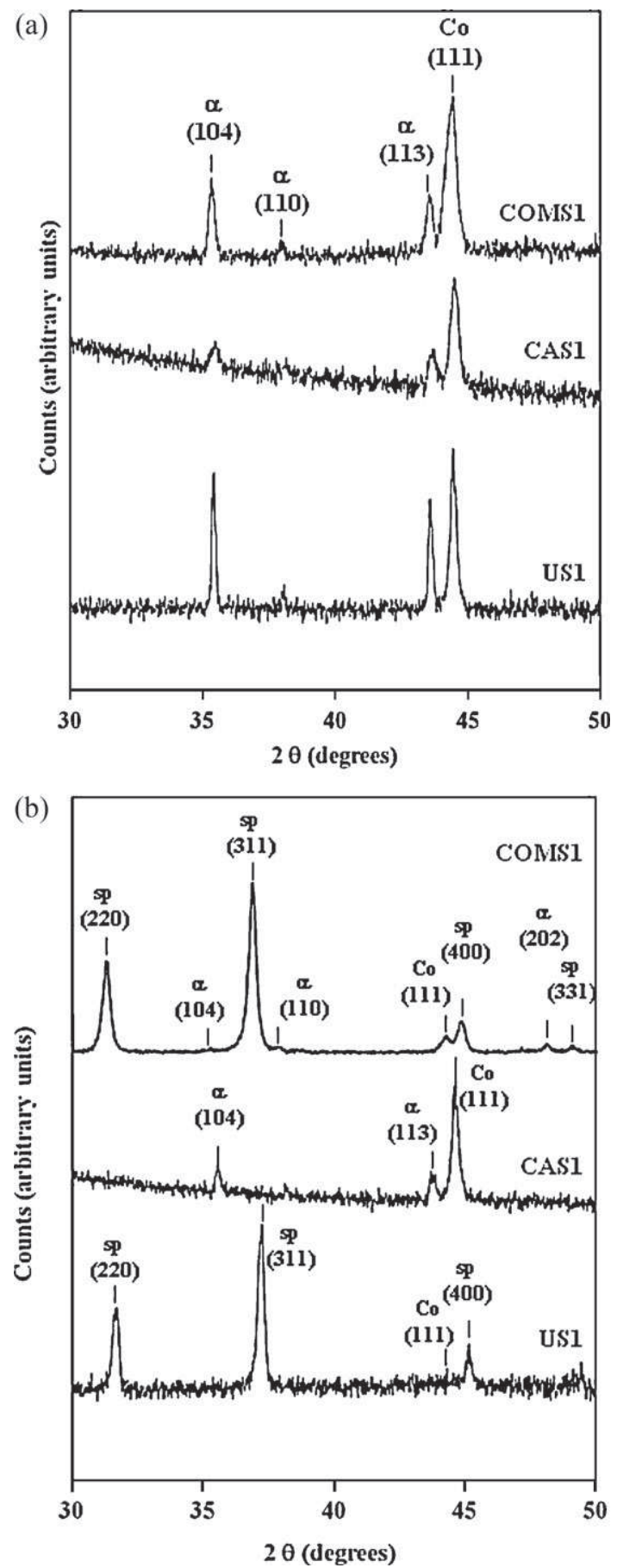

Fig. 3. XRD patterns of the COMS1, CAS1 and US1 specimens prepared by SPS. (a) Surface; (b) core.

US5. Note that for US4 the thickness is almost double than for US5 for a density only slightly lower (40.7 vs $\left.4.09 \mathrm{~g} / \mathrm{cm}^{3}\right)$. For US2, increasing the dwell time from 3 to $9 \mathrm{~min}$ (US2(3) and US2(9)) at $1300{ }^{\circ} \mathrm{C}$ favors the formation of a much thicker layer (436 vs $202 \mu \mathrm{m}$ ) at the expense of densification (3.5 vs $\left.3.8 \mathrm{~g} / \mathrm{cm}^{3}\right)$.

It is proposed that the cobalt particles are precipitated as described by reactions (1) and (2) during the SPS process because of a combination of high temperature and low $\mathrm{O}_{2}$ partial pressure:

$\mathrm{CoAl}_{2} \mathrm{O}_{4} \rightarrow \mathrm{Co}_{1-x} \mathrm{Al}_{2} \mathrm{O}_{4}+x \mathrm{Co}$

$\mathrm{Co}_{1-x} \mathrm{Al}_{2} \mathrm{O}_{4} \rightarrow(1-x) \mathrm{Co}+\mathrm{Al}_{2} \mathrm{O}_{3}+1 / 2 \mathrm{O}_{2}$

In reaction (1), the precipitation is not total and an aluminum-rich spinel $[10,11]$ is formed. For the surface of the specimens, or even the bulk of the sample from the more reactive powder (CA), the aluminum-rich spinel becomes unstable and the precipitation proceeds with the formation of $\alpha$ $\mathrm{Al}_{2} \mathrm{O}_{3}$ along with more $\mathrm{Co}$ particles. Note that reduction processes as described by reactions (3) and (4) cannot be ruled out, although reaction (4) is considered, from the analysis of earlier results [9], to be quite unlikely except for the extreme topmost surface of the sample:

$\mathrm{CoAl}_{2} \mathrm{O}_{4}+\mathrm{CO} \rightarrow \mathrm{Co}+\mathrm{Al}_{2} \mathrm{O}_{3}+\mathrm{CO}_{2}$

$\mathrm{CoAl}_{2} \mathrm{O}_{4}+1 / 2 \mathrm{C} \rightarrow \mathrm{Co}+\mathrm{Al}_{2} \mathrm{O}_{3}+1 / 2 \mathrm{CO}_{2}$

Thus, a higher specific surface area of the $\mathrm{CoAl}_{2} \mathrm{O}_{4}$ powder will favor the escape of gases $\left(\mathrm{O}_{2}, \mathrm{CO}_{2}\right)$ from the sample and the transformation into a $\mathrm{Co}-\mathrm{Al}_{2} \mathrm{O}_{3}$ composite will progress deeper into the sample. However, these processes are superimposed with those associated with densification and notably differential sintering phenomena: firstly, the more compact parts of the powder, i.e. those with the smaller grains and/or the more agglomerated ones, become still denser; then the precipitation/reduction processes occur, accounting for the formation of areas containing very small Co particles, in these dense parts, and areas with larger Co particles in the not yet dense parts where surface coalescence is still possible. Eventually, the latter areas become denser.

The powder with the higher specific surface area (CA, $78 \mathrm{~m}^{2} / \mathrm{g}$ ) is the more reactive but the CAS1 sample is the less dense one $\left(2.6 \mathrm{~g} / \mathrm{cm}^{3}\right)$. By contrast powder $U\left(18 \mathrm{~m}^{2} / \mathrm{g}\right)$ is the least reactive powder and produces the denser sintered specimen $\left(3.4 \mathrm{~g} / \mathrm{cm}^{3}\right)$. Thus, it seems that transformation hampers densification due to the evolved gas. The results on the different US specimens could also reflect the possible role of open porosity in the process. Applying the pressure early in the cycle at low temperature (US4 and US5) may favor the closing of porosity, which would decrease the possibility of $\mathrm{O}_{2}$ and/or $\mathrm{CO}_{2}$ leaving the sample, before the formation of Co by reaction (2) and/or (3) is thermally activated. The reaction zone and thus the composite layer are thinner, as observed in a previous study on the formation of $\mathrm{Fe}-\mathrm{Al}_{2} \mathrm{O}_{3}$ layers [9]. This also reveals that the relationships between transformation and densification are quite complex, because each one is able to hamper the other. Applying the pressure during the first minute of the 700$1300{ }^{\circ} \mathrm{C}$ ramp (as for US4) is a good compromise if one wants to obtain a $\mathrm{Co}-\mathrm{Al}_{2} \mathrm{O}_{3}$ composite layer about $100 \mu \mathrm{m}$ thick with a specimen density over $4 \mathrm{~g} / \mathrm{cm}^{3}$. Applying the pressure during the first minute of the room temperature $-700{ }^{\circ} \mathrm{C}$ ramp (as for US5) is a good compromise if one wants to obtain dense $\mathrm{CoAl}_{2} \mathrm{O}_{4}$, after removal by grinding of a thin composite layer. 

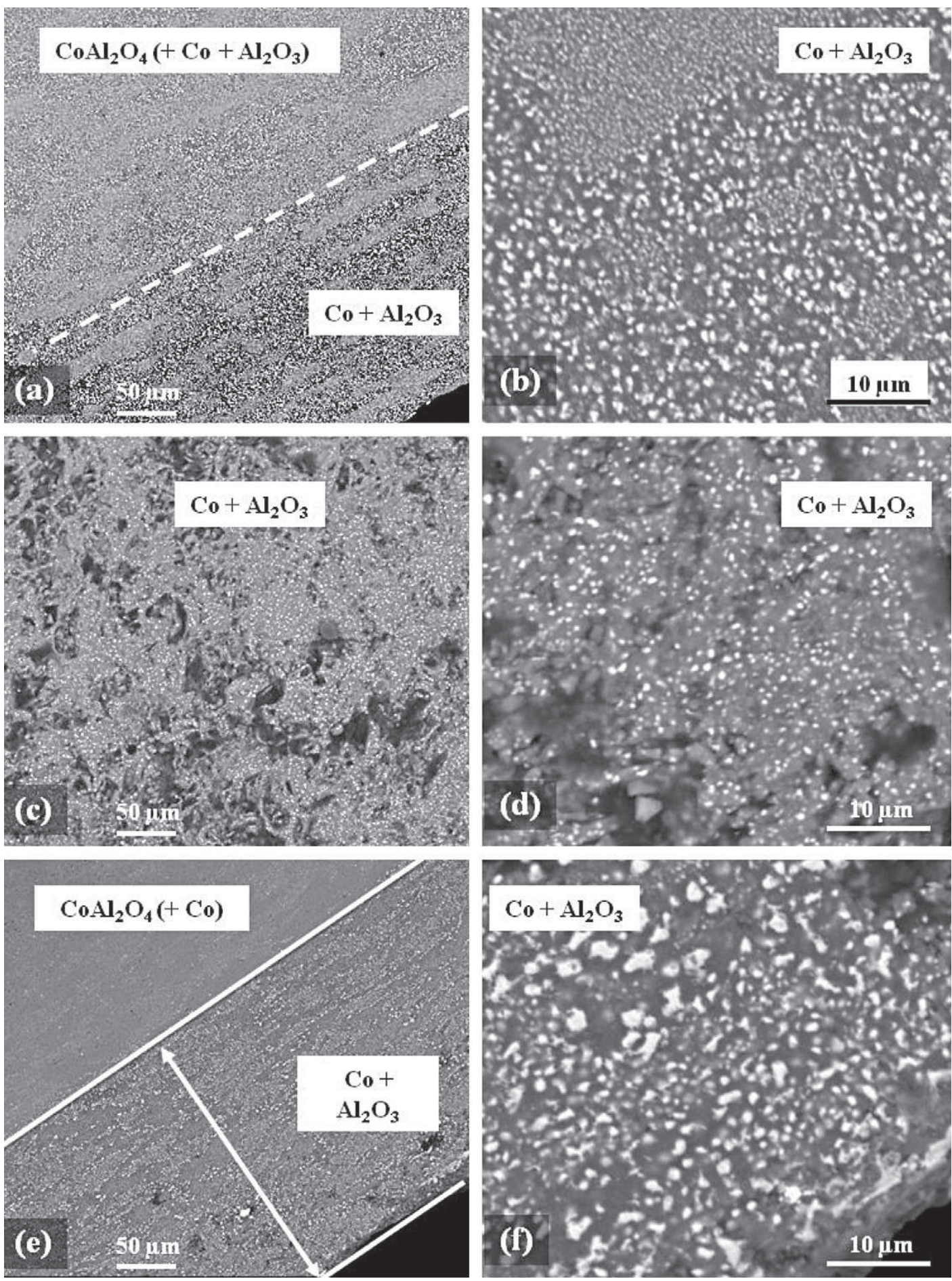

Fig. 4. FESEM images of a cross-section of the composites prepared by SPS: COMS1 (a and b), CAS1 (c and d) and US1 (e and f).

\subsection{Microhardness and friction behavior}

The sintering experimental conditions, density and thickness of the composite layer for specimens US6, US7 and COMS2 are summarized in Table 2. As mentioned in Section 2.3, the top side of the specimens was only slightly polished in order to reveal the surface composite layer and the bottom side was ground in order to reveal the core. For US6, the composite layer (Fig. 6a) shows areas containing Co particles of markedly different sizes (ca. 0.3 and $3.0 \mu \mathrm{m})\left(d_{\mathrm{Co}}-\right.$ Table 2$)$, as observed above for COMS1 and US1 (Fig. 4). The late application of the pressure favored the growth of the Co particles. For US7 (Fig. 6b), the residual porosity is significantly higher, and there are still two populations of Co particles (ca. 0.3 and $1.5 \mu \mathrm{m}$ ), although the growth has been limited. By contrast, there is only one population (ca. $0.3 \mu \mathrm{m}$ in size) for COMS2 (Fig. 6c), with only some coalescence at the grain junctions (particles ca. $1 \mu \mathrm{m}$ in size). The proportion of surface area occupied by the Co 


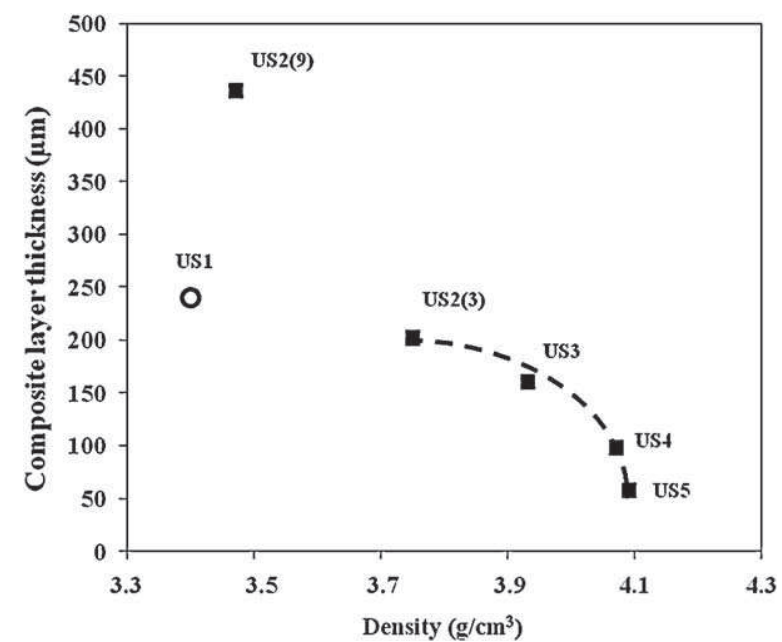

Fig. 5. Thickness of the surface composite layer versus the density of the specimens the US2, US3, US4 and US5 specimens prepared by SPS.

particles, determined by analysis of similar FESEM images, is equal to about 23, 24 and $17 \%$ for US6, US7 and COMS2, respectively $\left(S_{\mathrm{Co}}-\right.$ Table 2$)$. The HV values measured for the composite layers ( $\mathrm{HV}_{\text {surf }}$ - Table 2$)$ are fairly low for US6 and US7 (9.6 and 8.3 GPa, respectively), which could result from a lack of densification and an exaggerate growth of the Co particles [15]. The value found for the surface layer of COMS2 (13.6 GPa) corresponds to that reported [15] for a bulk $\mathrm{Co}-$ $\mathrm{Al}_{2} \mathrm{O}_{3}$ composite with a Co content equal to about $45 \mathrm{wt} \%$ and the size of the Co particles equal to about $0.75 \mu \mathrm{m}$. There are marked differences between the specimens regarding the friction behavior ( $\mu_{\text {surf }}-$ Table 2 and Fig. 7). For US7, the friction coefficient is always higher than for an $\mathrm{Al}_{2} \mathrm{O}_{3}$ specimen prepared by SPS [5]. The contact stabilization, to a value about double that for $\mathrm{Al}_{2} \mathrm{O}_{3}$, is slow, all the more so when the load is increased from 5 to $10 \mathrm{~N}$. This could reflect too much contact between the sample and the alumina ball because of a continuous pull-out of Co particles and $\mathrm{Al}_{2} \mathrm{O}_{3}$ grains, due to the low microhardness and relatively high porosity of the composite layer. By contrast, the friction coefficient for US6 and COMS2 is lower than for the $\mathrm{Al}_{2} \mathrm{O}_{3}$ specimen for a $5 \mathrm{~N}$ load (Fig. 7a) and the average values are low $\left(\mu_{\text {surf }}=0.27\right.$ and 0.23 , respectively). This could reflect the lubricating role of the Co particles. For a $10 \mathrm{~N}$ load (Fig. 7b), the friction coefficient for US6 and COMS2 is initially much lower than for $\mathrm{Al}_{2} \mathrm{O}_{3}$, but the curve gets progressively noisier starting at about 100 cycles and there is a strong increase at 180 cycles for US6, and a milder one for COMS at about 160 cycles, revealing major changes in the contact, probably because of the pulling-out and possible oxidation of the Co particles. The friction results are on the whole better for COMS2 than for US6, which could reflect a combination of higher hardness and a more homogeneous microstructure, with only one population of Co particles.

FESEM observations showed that the core of all three samples is made up of $\mathrm{CoAl}_{2} \mathrm{O}_{4}$ and a very small proportion of Co particles. The microhardness values are similar, in the range 14.9-15.9 GPa ( $\mathrm{HV}_{\text {core }}$ - Table 2). The average friction coefficients $\left(\mu_{\text {core }}-\right.$ Table 2$)$ are similar too, in the range
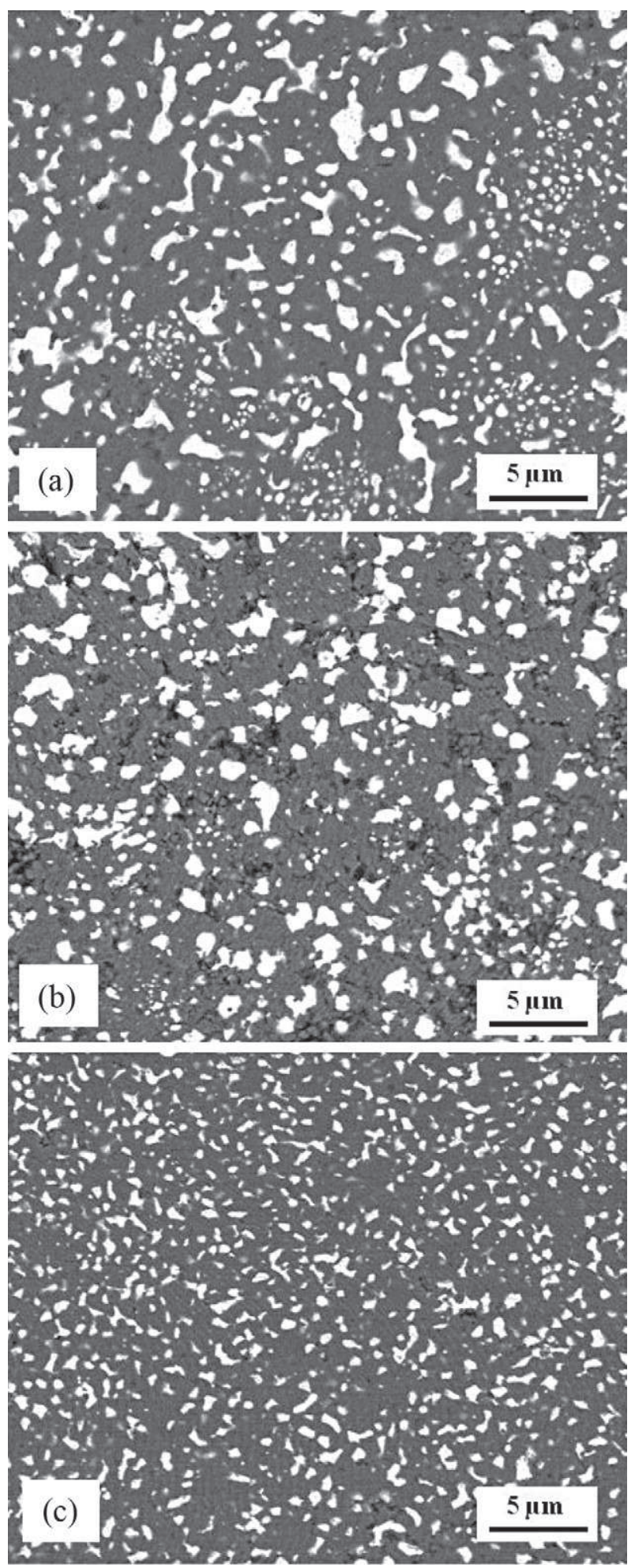

Fig. 6. FESEM image of the polished surface of US6 (a), US7 (b) and COMS2 (c).

$0.28-0.31$ for a $5 \mathrm{~N}$ load and in the range $0.30-0.34$ for a $10 \mathrm{~N}$ load. They are significantly lower than that of an $\mathrm{Al}_{2} \mathrm{O}_{3}$ sample (about 0.40). Courbiere et al. [16] have reported that $\mathrm{CoAl}_{2} \mathrm{O}_{4}$ layers grown on $\mathrm{Al}_{2} \mathrm{O}_{3}$ shows a similar or slightly lower friction coefficient than $\mathrm{Al}_{2} \mathrm{O}_{3}$, but show higher wear, in a test however totally different (steel ball, water lubrication, much higher load) 

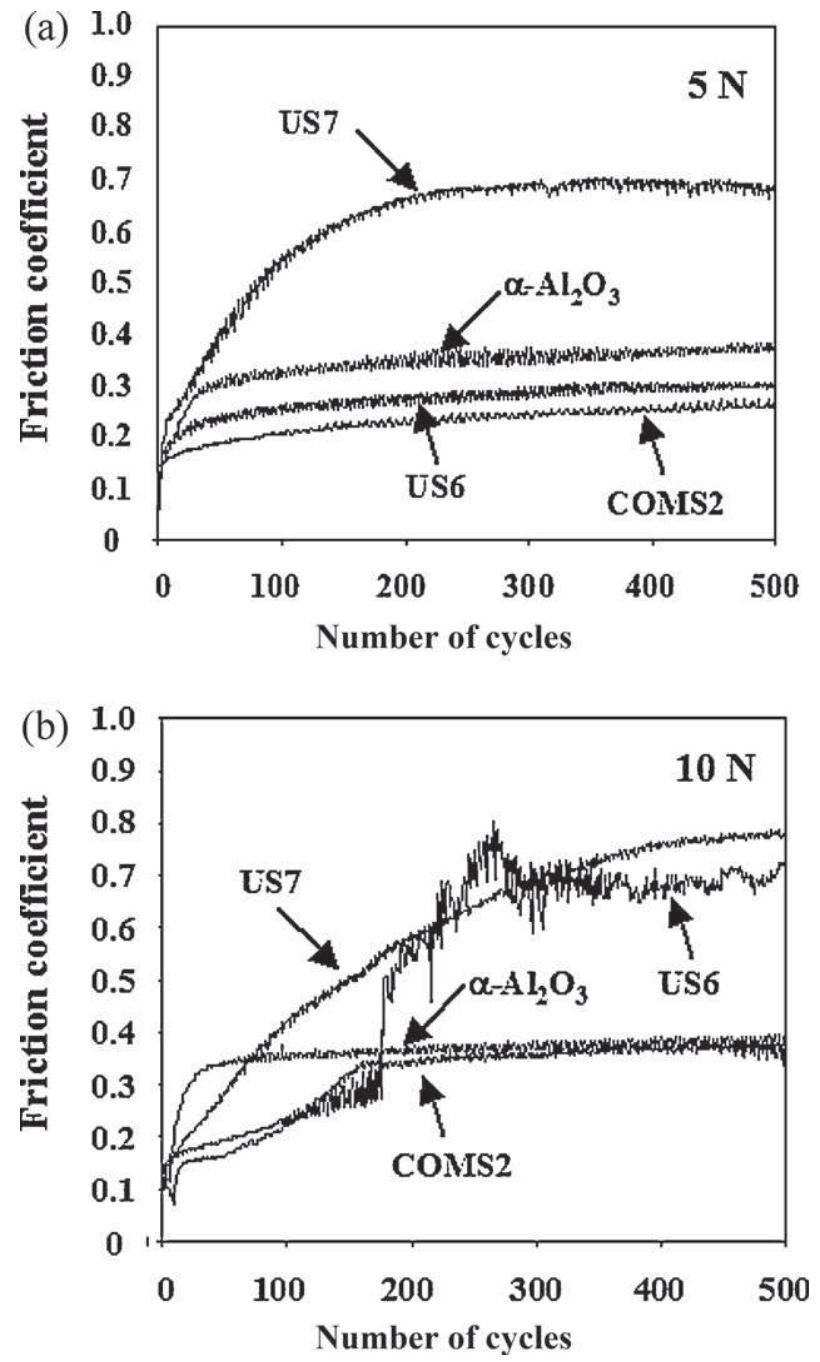

Fig. 7. Friction coefficient of the $\mathrm{Co}-\mathrm{Al}_{2} \mathrm{O}_{3}$ layers versus number of cycles for applied loads of $5 \mathrm{~N}$ (a) and $10 \mathrm{~N}$ (b) against an $\mathrm{Al}_{2} \mathrm{O}_{3}$ ball.

than the present one. To the best of our knowledge, it is the first time that such friction data are reported for bulk $\mathrm{CoAl}_{2} \mathrm{O}_{4}$. The tribological properties of $\mathrm{CoAl}_{2} \mathrm{O}_{4}$ warrant more studies, in particular wear will be reported elsewhere.

\section{Conclusions}

Materials with a $\mathrm{Co}-\mathrm{Al}_{2} \mathrm{O}_{3}$ composite coating over a $\mathrm{CoAl}_{2} \mathrm{O}_{4}$ core were prepared during SPS of $\mathrm{CoAl}_{2} \mathrm{O}_{4}$ powders. The Co particles are precipitated because of a combination of high temperature and low $\mathrm{O}_{2}$ partial pressure. A higher specific surface area of the $\mathrm{CoAl}_{2} \mathrm{O}_{4}$ powder favors the escape of gases $\left(\mathrm{O}_{2}, \mathrm{CO}_{2}\right)$ from the sample and thus the progress of the precipitation deeper into the core, but this hampers densification. Applying the pressure early in the cycle at low temperature to increase densification also favors the closing of porosity, thus decreasing the possibility of gases to leave the sample, resulting in a thinner composite layer. Applying the pressure during the first minute of the $700-1300{ }^{\circ} \mathrm{C}$ ramp allows one to obtain a $\mathrm{Co}-\mathrm{Al}_{2} \mathrm{O}_{3}$ composite layer about $100 \mu \mathrm{m}$ thick, with a specimen density over $4 \mathrm{~g} / \mathrm{cm}^{3}$. Applying the pressure during the first minute of the room temperature $-700{ }^{\circ} \mathrm{C}$ ramp permits to obtain dense $\mathrm{CoAl}_{2} \mathrm{O}_{4}$, after removal by grinding of a thin composite layer. The friction behavior of the $\mathrm{Co}-\mathrm{Al}_{2} \mathrm{O}_{3}$ composites against an $\mathrm{Al}_{2} \mathrm{O}_{3}$ ball depends strongly on the sample microstructure, residual surface porosity and applied load. For a $5 \mathrm{~N}$ load, specimens show a friction coefficient lower than that found for a reference $\mathrm{Al}_{2} \mathrm{O}_{3}$ specimen and the average values are low, which could reveal the lubricating role of the submicrometer Co particles. However, for a $10 \mathrm{~N}$ load, the initially very low friction coefficient shows a strong increase at 160-180 cycles, revealing some major change in the contact, probably because of the pulling-out and possible oxidation of the Co particles. Interestingly, $\mathrm{CoAl}_{2} \mathrm{O}_{4}$ was found to have a Vickers microhardness in the range 14.9-15.9 GPa and average friction coefficients $(0.28-0.31$ for a $5 \mathrm{~N}$ load and 0.30-0.34 for a $10 \mathrm{~N}$ load) lower than that of an $\mathrm{Al}_{2} \mathrm{O}_{3}$ sample (about 0.40). To the best of our knowledge, it is the first time that such friction data are reported for bulk $\mathrm{CoAl}_{2} \mathrm{O}_{4}$.

\section{Acknowledgments}

SPS was performed at the Plateforme Nationale CNRS de Frittage-Flash ( $\mathrm{PNF}^{2}$, Toulouse). Electron microscopy was performed at TEMSCAN, the "Service Commun de Microscopie Electronique", Université Paul-Sabatier.

\section{References}

[1] A.K. Dutta, A.B. Chattopadhyaya, K.K. Ray, Progressive flank wear and machining performance of silver toughened alumina cutting tool inserts, Wear 261 (2006) 885-895.

[2] S.T. Oh, S.J. Yoon, Y.H. Choa, Y.K. Jeong, K. Niihara, Wear behavior of nano-sized metal particles dispersed $\mathrm{Al}_{2} \mathrm{O}_{3}$ nanocomposites, Key Eng. Mater. 317-318 (2006) 369-372.

[3] G. de Portu, S. Guicciardi, C. Melandri, F. Monteverde, Wear behaviour of $\mathrm{Al}_{2} \mathrm{O}_{3}-\mathrm{Mo}$ and $\mathrm{Al}_{2} \mathrm{O}_{3}-\mathrm{Nb}$ composites, Wear 262 (2007) 1346-1352.

[4] P. Stempflé, F. Pollet, L. Carpentier, Influence of intergranular metallic nanoparticles on the fretting wear mechanisms of $\mathrm{Fe}-\mathrm{Cr}-\mathrm{Al}_{2} \mathrm{O}_{3}$ nanocomposites rubbing on Ti-6Al-V, Tribol. Int. 41 (2008) 1009-1019.

[5] J. Gurt Santanach, C. Estournès, A. Weibel, A. Peigney, G. Chevallier, Ch. Laurent, Mechanical and tribological properties of $\mathrm{Fe} / \mathrm{Cr}-\mathrm{Fe} \mathrm{Al}_{2} \mathrm{O}_{4}-\mathrm{Al}_{2} \mathrm{O}_{3}$ nano/micro hybrid composites prepared by Spark Plasma Sintering, Scr. Mater. 64 (2011) 777-780.

[6] T. Rodriguez-Suarez, J.F. Bartolomé, A. Smirnov, S. Lopez-Esteban, R. Torrecillas, J.S. Moya, Sliding wear behavior of alumina/nickel nanocomposites processed by a conventional sintering route, J. Eur. Ceram. Soc. 31 (2011) 1389-1395.

[7] A. Mukhopadhyay, R.I. Todd, Microstructure and mechanical properties of $\mathrm{Al}_{2} \mathrm{O}_{3}$ matrix nanocomposites produced by solid state precipitation, $\mathrm{J}$. Eur. Ceram. Soc. 30 (2010) 1359-1372.

[8] J. Gurt Santanach, C. Estournès, A. Weibel, A. Peigney, G. Chevallier, Ch Laurent, Sintering as a reactive sintering tool for the preparation of surface-tailored $\mathrm{Fe}-\mathrm{Fe}_{2} \mathrm{Ol}_{4}-\mathrm{Al}_{2} \mathrm{O}_{3}$ nanocomposites, Scr. Mater. 60 (2009) 195-198.

[9] J. Gurt Santanach, C. Estournès, A. Weibel, G. Chevallier, V. Bley, Ch. Laurent, A. Peigney, Influence of pulse current during Spark Plasma Sintering evidenced on reactive alumina-hematite powders, J. Eur. Ceram. Soc. 31 (2011) 2247-2254.

[10] A. Navrotsky, O.J. Kleppa, The thermodynamics of cation distribution in simple spinels, J. Inorg. Nucl. Chem. 29 (1967) 2701-2714.

[11] B. Hallstedt, Thermodynamic assessment of the system $\mathrm{MgO}-\mathrm{Al}_{2} \mathrm{O}_{3}, \mathrm{~J}$. Am. Ceram. Soc. 75 (1992) 1497-1507. 
[12] K.C. Patil, Advanced ceramics: combustion synthesis and properties, Bull. Mater. Sci. 16 (1996) 533-541.

[13] W. Li, J. Li, J. Guo, Synthesis and characterization of nanocrystalline $\mathrm{CoAl}_{2} \mathrm{O}_{4}$ spinel powder by low temperature combustion, J. Eur. Ceram. Soc. 23 (2003) 2289-2295.

[14] E. Flahaut, Ch. Laurent, A. Peigney, Catalytic CVD synthesis of double and triple-walled carbon nanotubes by the control of the catalyst preparation, Carbon 43 (2005) 375-383.
[15] W.P. Tai, T. Watanabe, Preparation and mechanical properties of $\mathrm{Al}_{2} \mathrm{O}_{3}$ reinforced by submicrometer Co particles, J. Mater. Sci. 33 (1998) 57955801.

[16] M. Courbiere, R. Trabelsi, D. Treheux, C. Beraud, C. Esnouf, G. Fantozzi, Growth and wear of superficial ternary metal oxides upon pure alumina, in: P. Vincenzini (Ed.), High Tech Ceramics, Elsevier Sc. Pub. B.V., Amsterdam, 1987, pp. 2599-2608. 